\title{
What We Talk About When We Talk About Development? A Review
}

\author{
Dewa Gede Sidan Raeskyesa \\ Universitas Prasetiya Mulya \\ dewa.sidan@pmbs.ac.id
}

\begin{abstract}
The purpose of this research is to revisit the meaning of development by seeking to answer the question; what is development? Also, we question whether the common and old wisdom of development objectives, economic growth (GDP), should continue to be the focus of studies. It concludes that development is when human aspects are become the objectives
\end{abstract}

Keywords: Economic Development, Economic Growth, Human Development

\begin{abstract}
Abstrak
Tujuan dari penelitian ini adalah untuk meninjau kembali makna pembangunan dengan berusaha menjawab pertanyaan; apa itu pembangunan?Kami juga mempertanyakan apakah pemahanan umum dari tujuan pembangunan yaitu Produk Domestik Bruto (PDB), harus terus menjadi fokus studi. Disimpulkan bahwa pembangunan adalah ketika aspek manusia menjadi tujuan
\end{abstract}

Kata Kunci: Pembangunan Ekonomi, Pertumbuhan Ekonomi, Pembangunan SDM

\section{Introduction}

According to Brookings Global Economy and Development (2007), it has been recognized that there are several major global development challenges within the society. The issues start from environment, conflict and poverty to health. Furthermore, inequality in income becomes other important issue for country's development process, from developed to developing countries are experiencing the unequal societies (see figure 1.1). Those interconnected issues are matters for country's development process. For example, despite of the moderate global economic growth (World Bank, 2018, p.4-5), the world is facing global inequality which would give zero opportunity to the poor people to access the education and financial markets. It means, there will be a challenge to build the productivity capabilities (International Monetary Fund, 2018). Moreover, inequality matters due to its impact to shake the socio-political stability, which will lead into unreliability economic environment and lack of investment (Alesina \& Perotti, 1996). As domestic and foreign investment are necessary for country's economic development, both in developed nations (Pegkas, 2015) and emerging countries like Indonesia (Zulkarnain et.al, 2015). In addition to that, income inequality could be a threat which slowed down the economic growth and the effort in poverty alleviation (Aji, 2015).

On the other hand, these development problems could not be captured by gross domestic product
(GDP), which often used by economic scholars as an economic development measurement. The influence of GDP (per capita) often being against due to the incapability to capture human development progress. For example, the importance of satisfaction towards basic needs such as fresh air, access to nature and serenity are not represent within GDP model. Moreover, in terms of income distribution GDP per capita does not pay attention to the distribution process, which means the indicator neglects the existence of unequal opportunities for individual development (van den Bergh, 2008). This raise a question; is GDP still fit as our main development purpose?

On the other side, one may have stated that development is about increasing income (Anand and Ravallion, 1993, p. 133-134). While others may think that humans, as agents in economic activities, should be the target for the development process; this was proposed by the United Nations Development Program, together with the Human Development Index. Moreover, situations such as poverty, unemployment, and inequality are suggested by Dudley Seers (1969) to become the issues to understand more about the essence of development. He believes those aspects could be the important determinants of country's development.

Therefore, together with various perspectives of development, this research attempts to revisit the meaning of development and determine the real objectives for development and the development 
Figure 1. Gini coefficient cor rections 2012-2014

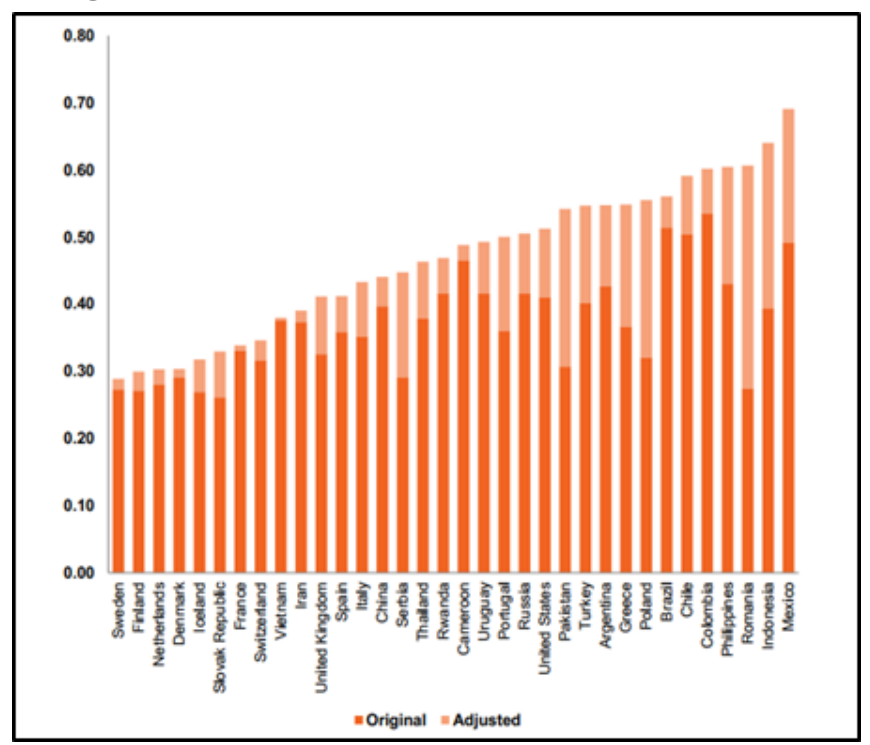

Source: Oxfam International (2018, p. 21)

aspects that should be focused on. After the introduction, a literature review on the development framework, as a conceptual basis, will be presented. The third chapter provides a discussion about human and societal aspects as a development objective. This question the old wisdom of the development objective of economic growth. In Chapter Four, we present the conclusions and discussion.

\section{Theoretical Review}

\section{Development Objectives and Values}

"What are the necessary conditions for a universally acceptable aim, the realization of the potential of human personality?" - Gandhi (Seers, 1969)

Development is a dynamic process. It consists of humans and societal aspects. It is important to have basic values that can be used as a conceptual foundation and direction to better understand the essential meaning of development. According to Todaro and Smith (2012, p. 21-23), there are three core values of development: 1) Sustenance, 2) SelfEsteem, and 3) Freedom from Servitude.

\section{Sustenance: The Ability to Meet Basic Needs}

To maintain their lives, humans have several basic needs: food, health, shelter and protection. When one of these needs is not met, it is easier for that person to fall into an absolute condition, where it is difficult for them to develop. It is necessary to improve and equally distribute the basic needs to the people; this is the objective necessary to implement this value. Therefore, an increase in individual income and higher employment is an important, but not adequate, condition for development
(Todaro and Smith, 2012).

To benefit the development process, one fundamental thing that can be considered is the provision of health care to all members of society. This is important, as "Health is a direct source of human welfare and also an instrument for raising income levels" (Bloom et al., 2008, p. iv). Moreover, it might seem as if there is a relationship between the level of income and the health conditions. In terms of a country's policy, some countries might think they would achieve better health conditions if they had more income. As a result, they will make income growth their priority. However, there are countries where health is a priority of the government agenda, because they believe that better health leads to higher incomes.

Health is a type of human capital that builds life prosperity. Being contaminated by diseases or illnesses would impact human productivity and hinder the development process. Moreover, health plays a role in human development. This is because healthy workers are more productive than sick workers. Regarding children, health conditions define their cognitive development and ability to learn and participate in the education process (Bloom et al., 2008, p. 1).

Health is an aspect of human capital. Hence, health could be an "economic engine" (Mirvis et al., 2008, p. 30) for a country. As mentioned previously, health could increase individual productivity and keep down the company's costs in relation to the health benefits of workers. Moreover, by having decent health conditions (e.g., less pain and stress or depression as a worker), companies would save $\$ 44$ billion to $\$ 61$ billion annually (Mirvis et 


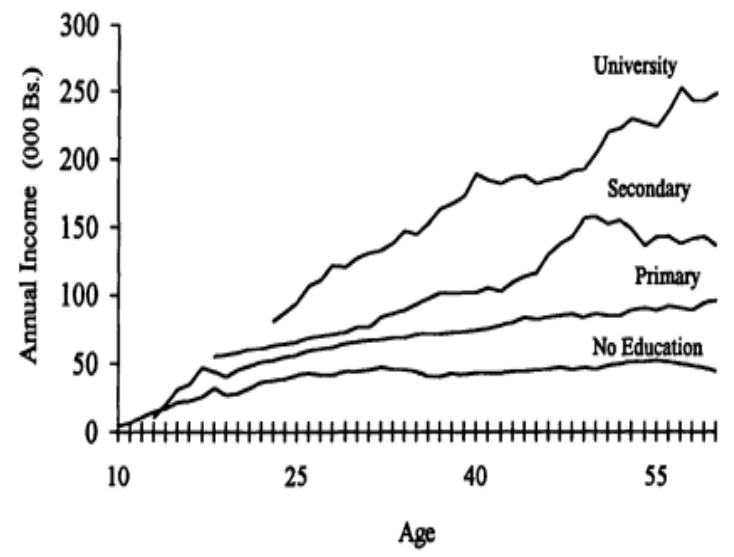

Figure 2. Age-earning Profile by Level of Education - Venezuela, 1989

Source: Psacharopoulos, G. (1995).

al., 2008, p. 38). In addition, a healthy population positively impacts the economic well-being of every community and the country's macroeconomic conditions.

Moreover, people save more money when they are healthier, which implies they will make more investments. On the other hand, people with poor health conditions spend most of their money on health care services and care less about their future needs. Hence, poor health conditions hinder investments. In addition, society with poor health performance will undermine not only the society cohesiveness but also the process of knowledge and technology transfers. As a result, it will decrease the probability of foreign investment for the nation. Therefore, a high level of health in a population will encourage investments and increase social cohesion within the society. This leads to political stability and helps the government's performance, especially in developing countries (Mirvis et al., 2008).

The dream of using health as an economic engine cannot be accomplished without equal health opportunities. Professor Woodward from the Wellington School of Medicine states that equality is achieved by removing and eradicating all the fac- tors beyond the individual's control that could have a negative impact on the development process (Woodward and Kawachi, 2000, p. 924). The government should assure that people are healthy and obtaining the proper level of nutrition. This is because all variables that are beyond a person's control will define a person's opportunities in life. The World Bank (2016) believes that by reducing inequality in opportunities in health, especially at birth, this will impact people's income, and their abilities as they grow up. In other words, by having the same opportunity, all people, especially children, will have an equal start to their lives.

\section{Self-Esteem: To be a Person}

The second value emphasizes that having a selfesteem is a fundamental element of building a good life. This self-esteem can be acquired by having self-respect, dignity, and recognition. The nature and description of the self-esteem would be different from one to another society, due to cultures and customs. It is beneficial to increase the living quality by improving the per capita income, providing better opportunities and increasing the quality of education, while, at the same time, considering culture and human values (Todaro and Smith, 2012).

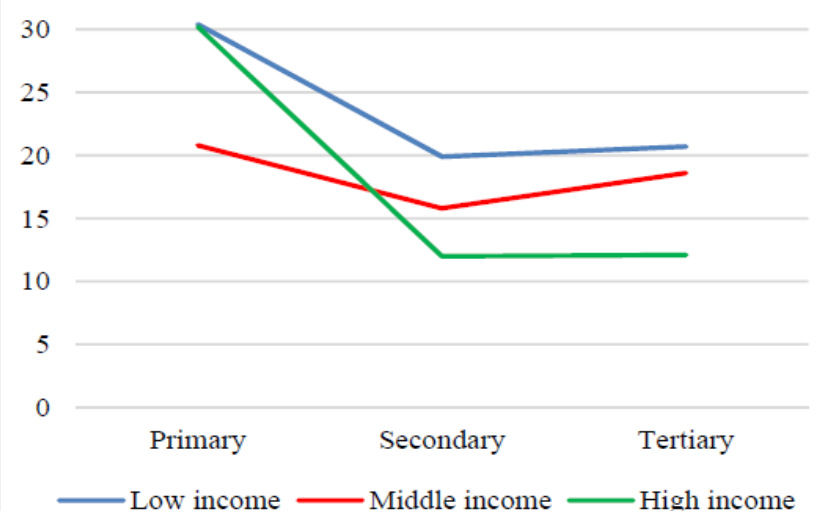

Figure 3. The Structure of Private Returns

Source: Psacharopoulos, G., and Patrinos, H. A. (2018) 
Focus on the expansion of opportunities for people to have a better education will give them an opportunity to participate in and contribute to society (Figure 1). People without a proper education and professional skill training may have a higher likelihood of having a lower income (Psacharopoulos, 1995) and being unemployed.

Furthermore, Psacharopoulos and Patrinos (2018) found that education provides beneficial returns to the individual, especially women. As a result, the work on women's empowerment should continue. Moreover, the private returns are higher in developing countries than in the high-income group (Figure 2).

On the other side, it is important to increase the self-esteem of the individual by creating a positive societal environment - social capital (Huegaerts et al., 2018). Self-esteem contributes to a personal attainment on education. In other words, people with a high self-esteem will more likely obtain success in educational achievement. Thus, it will accommodate them to have a higher possibility to have an occupation and better income. Both of these variables affect their self-esteem (Araujo and Lagos, 2012). On the other hand, the situation of not having an occupation will contribute to selfesteem in a negative way. Goldsmith et al. (1997) found that a jobless young female has a lower selfesteem than a young female with a job. Being jobless can have a detrimental effect on an individual's self-esteem, especially when the person has decided to blame themselves for being jobless. Joblessness also influences a person's well-being (Meer/ Wielers, 2016).

\section{Freedom from Servitude: To be Able to Choose}

The value of human freedom is necessary for the process of development. The increasing freedom capacity for humans is meant to widen the options for societies and the element within to reach the social development goals. This could be reached by ensuring 'personal security, freedom expression, political freedom, and law enforcement' for all (Todaro/Smith, 2012, p. 22). Furthermore, increasing the capacity of human freedom is conducted by expanding their economic freedom. In this way, they will have a certain number of properties or wealth that will assist them in having more options and social activities to choose from (Todaro and Smith, 2012).

Gehring (2013) explained that economic freedom is implemented by having fewer unnecessary regulations that bind an individual, as well as a low inflation level, and proper law enforcement. This will ensure that property rights are beneficial to in- crease the level of social well-being, especially for people in developing countries. In the business realm, the importance of economic freedom will foster innovative activities in a corporation, due to the corporation's ability to produce a better financial situation that promotes innovation (Zhu et al., 2016). In terms of individual benefits, economic freedom could help people to have more options to choose from for their consumption and obtain better nutrition through the free trade channel. This is especially true for citizens in developing countries (Lawson et al., 2016). However, this economic freedom could be destroyed by letting a few members of society control the majority of the income. As explained by Islam (2018, p. 13), an increase in the wealth inequality level will have a negative effect on the economic freedom variables due to "[...] lower protection in property rights, less access to sound money and less freedom in international trade $[\ldots] "$.

\section{Should economic growth become the aim of development?}

In the economics realm, the "economists have long been a natural constituency in favor of growth" (Stiglitz, 2005, p. 128). Moreover, it is common to consider the Gross Domestic Product (GDP) as a measurement of the success of a country's economy. Thus, GDP automatically plays an important role in the economic world, with its ability to put everything into numbers and figures (Széll, 2011, p. 546).

Interestingly, in 2016, during the World Economy Forum in Davos, a number of prominent economists (e.g., Joseph Stiglitz, Christine Lagarde) expressed their concern that GDP is a poor measurement of the health of our economies. Furthermore, Stiglitz stated that "GDP is not a good measure of economic performance and well-being". This statement was supported by the work of Badrudin et al. (2018), who concluded that economic growth does not contribute to the well-being of the people in Sulawesi, Indonesia. Tiemstra (2008, pp. 431-432) noted that "GDP is a measure of market activity, not welfare" and expressed his idea to make humans the goal of economic activity by raising the question of "what economic activities really contribute to human well-being [...]?"

During the process of chasing economic growth, there is still a basic expropriation of the people. More specifically, at least one out of every nine people in the world are starving. One out of every three people have poor nutrition. Minorities and certain ethnic groups are often exempted from education, employment and political positions; this sit- 
uation creates poverty and increases criminality. Moreover, there are over 370 million native people in 70 countries dealing with discrimination to access education in their own language and to have land, water, forest and intellectual property rights. Even worse, 18,000 people around the world die every day from a bad environment and air pollution (Human Development Report, 2016, p. 5). Furthermore, it is believed that the expansion of economic growth will lead to a higher portion of $\mathrm{CO}_{2}$ emissions in our environment (Mikayilov et al., 2018). World leaders need to change their way of thinking by filling our economic growth with active employment, poverty alleviation and less inequality within a sustainable environment (Nayyar, 1999, p. 2); these leaders need to focus on "people as the core of development" (Stiglitz, 2006).

\subsection{Development is about the essence of society}

Professor Myrdal (1974) stated that development is "the movement upward of the entire social system." He believed that the social system contains two elements: economics and all noneconomic elements. For the economic elements, the production side is usually measured by GDP. Noneconomic elements include education, health, the allocation of authority in society and political institutional performance. He also emphasized that our social system is very dynamic. This is due to the circular causation between the two elements, which means that the changes in one element will affect other elements. These elements should respond to the changes by creating secondary changes. Thus, according to Myrdal, our society is living in an interdependent condition (Myrdal, 1974, pp. 729).

Interestingly, this view was also supported by Dr. Hugo Slim, from Oxford Brookes University, a former senior researcher at the Save the Children Fund, who was the Head of Policy at the International Committee of the Red Cross in Geneva. Essentially, Slim believes that development is about changes with certain advancements. This advancement drives the spirit for improvement in many ways. Slim further emphasizes the importance of continuity, as one of the values in understanding development. He notes that to determine how to make changes stable, something mutual must be created within the society itself. A vision or purpose that makes sense for people and makes them stay together occurs, because it is in line with their own values and competence. Therefore, Dr. Hugo Slim thinks that development must be compatible in many terms, including economic, cultural and environmental (Slim, 1995, p. 143).

Moreover, by being compatible with those terms, we can produce authentic development, which is established from the values or purposes within the society itself. In other words, the authentic development is not an imitation of another country's or society's development. This authentic development is not about likeness or making all things become the same. It is about preserving and flourishing the differences between each other, which, in the end, generates diversity. Therefore, a country's real development can only "[...] be achieved by people and cannot be done to people" (Slim, 1995, p. 144). The needs, values and purposes of a country should become a clarification of the development they want to build (Ibrahim, 1986, p. 1).

\subsection{Development is about humans}

Humans are the subject and the object of development. This is why Ibrahim $(1986$, p. 2) said that "[...] the focus of a development process is man himself [...]". Moreover, he believes that all agendas in development should correspond with human nature. One of the ways to commit to this purpose is by respecting human freedom and promoting the participation of all people at all levels, to increase their capacity to be independent (Ibrahim, 1986, p. 3 ). Interestingly, this perspective of human freedom as development is also shared by the United $\mathrm{Na}$ tions Development Programme. The foreword in their human development report emphasizes the importance of human freedom to achieve his or her potential in life independently (UNDP, Human Development Report, 2016, p. iii).

Furthermore, by making human freedom our development goal, the limited views of development from the former time are extended (e.g., defining development with GDP or individual earnings). Countries are considered as developed when they have a good performance in industrialization with technological advances in a modern society. These definitions are not entirely wrong. More specifically, the increase in some individual incomes will become a significant means to expand freedom, which provides benefits to the other components in a society. However, freedom also relies on other elements (e.g., education, infrastructure, health care services, and the freedom to express personal opinions and to participate in the process of political systems) (Sen, 2001, p. 3). The freedom we are concerned about underlines the importance of not only having more, but also about being more. This sort of development is not like a good that we can just simply measure by statistics in GDP. It is beyond economic terms (Slim, 1995, p. 145). Therefore, perhaps we should ask ourselves 
why freedom is important for human development.

The essence of freedom is important for humans, because it enriches human lives. This enrichment includes the ability to avoid several deprivations (e.g., malnourishment, famine, illness transmission, premature death, being able to have a decent education, rights for participating in political processes and expressing opinions). Therefore, all the valuations of development should be confirmed by this view; the expansion of basic freedom is an object or end of development. These freedoms, such as the freedom to participate in the political process, may not have indirect contributions to other traits of development, but will help the process of development. Therefore, by focusing on the fundamental human freedom, it will be possible to define a way to achieve the development goals (Sen, 2001).

According to Sen (2001), there are several things that focus on various rights and opportunities, which give humans the ability to live more freely. The first thing is freedom related to political activity, or political freedom, which means that people have a chance to decide who should do the task of government and on what values or purposes. They also have freedom to express their own opinions and have fair news in the media.

The second is focuses on the economic activity of everyone. In his book titled, 'Development as Freedom,' Sen (2001) explains that this means that every individual should have the opportunities and rights to make use of economic resources to do their activity (e.g., production, consumption). At the same time, he also mentions the importance of the distribution activity and the ability to have access to finances within society. The third tool, Sen argues how education and healthcare can provide opportunities to people to live better. He explains how these variables can provide a firm foundation for everyone's private life and increase their participation in economic and political activities.

The fourth thing, to expand basic human freedom, is inspired by the foundation of trust within society. Sen explains how important transparency and openness are to avert corruption, unfair actions, and fraud in financial activities. Finally, for the fifth, Sen believes the creation of safety nets for society is important to prevent people from experiencing unpredictable events, which may become a reason to experience a despicable misery (e.g., hunger, fatality). This idea could be managed by a regulation from an institution to provide an unemployment benefit and legal additional income (Sen, 2001, p. 36-40).

Another part of humans, which counts as an im- portant aspect of development, would be human relationships. It is believed that the reason for a failure in a development is because of the defects in human relationships. Unfair behavior takes place at all scopes, from the international to the local community level. The relationships between ethnicity and gender could be an important factor for shaping or demolishing the authentic development at the community level (Slim, 1995, p. 146).

\subsection{Development Model}

There are several ideas in regards of development model. One of many that focuses to human relationships comes from Indonesia. It is derived from the Hindu-Bali philosophy called Tri Hita Karana.

The Tri Hita Karana philosophy believes there are three causes of goodness, which emphasize the importance of a harmonic relationship between humans and their fellow human, humans and their gods, and finally, humans and their environment (Samadhi, 2002, p. 14). It is believed that the fulfillment of all three aspects of a relationship in the Tri Hita Karana brings sustainability in development (Knight et al., 1997, p. 94). This relationship, especially between humans in a local and international community, would be an advantage to development processes (Slim, 1995, p. 146). If there is a dysfunction in the relationship, it will be a barrier to create a positive understanding in agreement and cooperation, or, as Stanley (2003, p. 5) describes, it is a social cohesion, where there is a willingness to cooperate within the society's members

On the other side, developing countries could improve their economic development performance by learning from another framework. This development framework called as Social Market Economy, which suggests maintaining price stability in order to generate savings and investment opportunities which lead to higher economic growth. As investment could be financed by debt, it is important to have a balanced government budget to support the welfare objectives. Therefore, it is important to maintain the internal savings rate to reduce the risks and dependency from foreign investment. On the other side, to improve the human capital capacity will expand innovation activities which led to higher economic growth (Benecke, 2008). It is necessary due to developing countries are often use debt to operate their economy and when debt becomes a part of GDP, it gives negatives impact both in short and long run (Siddique et al., 2016).

\section{Discussions and Conclusions}

It is common to make an economic growth is the 
main objective of development. As a result, many countries focus on increasing their wealth, income and GDP. However, those variables should not be the only goals of development. As expressed by Friedrich List, in Jun et al. (2016), power in production is more important than wealth; here, humans and social capital are considered the productive powers.

Furthermore, Stiglitz (2013, p. 117) has explained that "Whenever we diminish equality of opportunity, we are not using one of our most valuable assets-our people- in the most productive way." Therefore, it is important to put people at the core of the development objectives. One may attempt to focus on a long-term development goal by providing all people with equal access to education and health services. As Becker (1992, p. 85) said, "Education and training are the most important investment in human capital", while "health is a direct source of human welfare and also an instrument for raising income levels" (Bloom et al., 2008 , p. iv). Moreover, to maintain social capital and relationships within the society, decreasing the inequality level should become an important development objective. Finally, to drive the economic growth by innovation activities would be beneficial for the country's development process and maintain the balance of government budget in order to decrease the nation's dependency on foreign debt or investment.

Based on the explanation above, there are things beyond than just economic growth and income when we talk about development. One may say that it is important to encourage social and human rights aspect in order to make the development viable (Redek and Ivković, 2013, p. 13). Local wisdom such as Tri Hita Karana from Balinese society could be an example for a model that focus on social capital.

At last, "development is about transforming the lives of the people, not just transforming economies" (Stiglitz, 2013, p. 50). Therefore, it would be necessary that focus should be placed on the $\mathrm{Hu}-$ man Development Index and other socio-economic indicators, in relation to development aims.

\section{References}

Abu Siddique, E.A. Selvanathan, Saroja Selvanathan. (2016). The impact of external debt on growth: Evidence from highly indebted poor countries. Journal of Policy Modeling. https://doi.org/10.1016/ j.jpolmod.2016.03.011.

Aji, Priasto. (2015): "Summary of Indonesia's Poverty Analysis”. ADB Papers on Indonesia \#4,
Asian Development Bank

Alesina, Alberto and Roberto Perotti. Income Distribution, Political Instability, And Investment, "European Economic Review, 1996, vol. 40(6,Jun), 1203-1228. (DOI): 10.3386/w4486

Anand, S., \& Ravallion, M. (1993). Human development in poor countries: On the role of private incomes and public services. The Journal of Economic Perspectives, 7(1), 133-150.

Araujo, P., \& Lagos, S. (2013). Self-esteem, education, and wages revisited. Journal of Economic Psychology, 34, 120-132. doi: 10.1016/j.joep. 2012.12.001

Badrudin, R., Kusuma, M., \& Wardani, R. (2018). The inclusive economic development model in Sulawesi Island. Economic Journal of Emerging Markets, 10(2), 128-136. Doi: 10.20885/ejem.vol10.iss2.art2

Becker, G. (1992). Human capital and the economy. Proceedings of the American Philosophical Society, 136(1), 85-92.

Becker, G. (1962). Investment in human capital: A theoretical analysis. Journal of Political Economy, 70(5), 9-49.

Benecke, Dieter. W. (2008). The Social and Ecological Market Economy - A Model for Asia? Ed. By Deutsche Gesellschaft fürTechnische Zusammenarbeit (GTZ) GmbH, Eschborn 2008, p.23-52. Konrad Adenauer Stiftung

Bloom, D. E., Canning, D. (2008). Population health and economic growth. Commission on Growth and Development Working Paper \#24.

Brookings Global Economy and Development. (2007). Top 10 Global Economic Challenges; An Assessment of Global Risks and Priorities. The Brookings Institution.

Knight, D., Mitchell, B., \& Wall, G. (1997). Bali: Sustainable development, tourism and coastal management. A mbio, 26(2), 90-96.

Gehring, K. (2013). Who benefits from economic freedom? Unraveling the effect of economic freedom on subjective well-being. World Development, Vol .50, pp. 74-90. Doi: 10.1016/ j.worlddev.2013.05.003

Goldsmith, A., Veum, J., \& Darity, W. (1997). Unemployment, joblessness, psychological wellbeing and self-esteem: Theory and evidence. The Journal of Socio-Economics, 26 (2), 133-158. Doi: 10.1016/s1053-5357(97) 90030-5

Huegaerts, K., Spruyt, B., \& Vanroelen, C. (2018). Youth unemployment and mental health: The mediating role of embodiment. Societies, 8 
(2), 43. Doi: 10.3390/soc8020043

Human Development Report. (2016). Human development for everyone. Published for the United Nations Development Programme.

Ibrahim, A. (1986). Development, values and changing political ideas. Sojourn: Journal of Social Issues in Southeast Asia, 1(1), 1-7.

International Monetary Fund. (2018). Building a Shared Future. IMF Annual Report. https:// www.imf.org/external/pubs/ft/ar/2018/eng/

Islam, M. (2018). Wealth inequality, democracy and economic freedom. Journal of Comparative Economics. Doi: 10.1016/ j.jce.2018.01.002

Jun, B., Gerybadze, A., \& Kim, T-Y. (2016). The legacy of Friedrich List: The expansive reproduction system and the Korean history of industrialization, Hohenheim Discussion Papers in Business, Economics and Social Sciences, No.02-2016, Universität Hohenheim, Fakultät Wirtschafts- und Sozialwissenschaften,Stuttgart,http://nbn-resolving.de/ urn:nbn:de:bsz:100-opus-11894

Lawson, R., Murphy, R., \& Williamson, C. (2016). The relationship between income, economic freedom, and BMI. The Royal Society for Public Health. Published by Elsevier Ltd. All rights reserved. http://dx.doi.org/10.1016/ j.puhe.2016.01.020

Meer, P. V. D., \& Wielers, R. (2016). Happiness, unemployment and self-esteem. Unpublished. Https://doi.org/10.13140/rg.2.2.24007.50080

Mikayilov, J., Galeotti, M., \& Hasanov, F. (2018). The impact of economic growth on $\mathrm{CO} 2$ emissions in Azerbaijan. Journal of Cleaner Production, 197, 1558-1572. Doi: 10.1016/ j.jclepro.2018.06.269

Mirvis, D., Chang, C., \& Cosby, A. (2008). Health as an economic engine: Evidence for the importance of health in economic development. Journal of Health and Human Services Administration, 31(1), 30-57.

Myrdal, G. (1974). What is development? Journal of Economic Issues, 8(4), 729-736.

Nayyar, D. (1999). Globalization and development strategies, High - level Roundtable on Trade and Development, UNCTAD, TD $(X) / R T .1 / 4$, New York and Geneva: United Nations

Oxfam Briefing Paper. (2018). Reward Work, Not Wealth.ISBN 978-1-78748-135-0.

DOI:10.21201/2017.1350.www.oxfam.org

Pegkas, Panagiotis. (2015). The impact of FDI on economic growth in Eurozone countries. The Journal of Economic Asymmetries. https:// doi.org/10.1016/j.jeca.2015.05.001
Psacharopoulos, G. (1995). The profitability of investment in education: Concepts and methods (English). Human capital development and operations policy working papers; no. HCO 63. Washington, DC: World Bank.

Psacharopoulos, G., Patrinos, H. A. (2018). Returns to investment in education: A decennial review of the global literature. Policy Research Working Paper; No. 8402. World Bank, Washington, DC. (C) World Bank. Https:// openknowledge.worldbank.org/

handle/10986/29672 License: CC BY 3.0 IGO."

Redek, T., \& Ivković, A. (2013). 'More is Better' as a Challenge to Sustainable Development: Theoretical and Empirical Approach. Mediterranean Journal Of Social Sciences, 4(2), 13. doi: 10.5901/ mjss.2013.v4n2p11

Samadhi, N. (2002). Ethnicity and urban design in Bali: Reinventing Desa Adat as an urban design unit. Traditional Dwellings and Settlements Review, 14(1), 14-15.

Seers, D. (1969). The meaning of development. Institute of Development Studies. IDS Communication. 44

Sen, A. (2001). Development as Freedom. Oxford: Oxford University Press.

Slim, H. (1995). What is development? Development in Practice, 5(2), 143-148.

Stanley, D. (2003). What do we know about social cohesion: The research perspective of the federal government's social cohesion research network. The Canadian Journal of Sociology / Cahiers Canadiens De Sociologie, 28(1), 5-17.

Stiglitz, J. E. (2015). Inequality and economic growth. The Political Quarterly, 86: 134-155.

Stiglitz, J. E. (2013). The Price of Inequality: How Today's Divided Society Endangers Our Future. W.W. Norton \& Company.

Stiglitz, J. E. (2006). Making Globalization Work. New York: W.W. Norton \& Co.

Széll, G. (2011). Beyond GDP. Indian Journal of Industrial Relations, 46(4), 545-552.

Tiemstra, J. (2008). Rethinking the costs of economic growth. Association for Social Economics Presidential Address, 2008. Review of Social Economy, 66(4), 423-435.

Todaro, M. and Smith, S. (2012). Economic Development - 11th Edition. Boston: Pearson Addison Wesley.

van den Bergh, Jeroen C.J.M. (2009). The GDP paradox. Journal of Economic Psychology.https://doi.org/10.1016/ 
j.joep.2008.12.001.

Weisskopt, T. (2013). What kinds of economic inequality really matter? Indian reEconomic Review, 48(1), 39-58.

Woodward, A., \& Kawachi, I. (2000). Why reduce health inequalities? Journal of Epidemiology and Community Health (1979-), 54(12), 923929.

World Bank. (2018). Global Economic Prospects, June 2018: The Turning of the Tide? Washington, DC: World Bank. doi: 10.1596/978-1-4648-1257-6.

Zhu, H., \& Zhu, S. (2016). Corporate innovation and economic freedom: Cross-country comparisons. The Quarterly Review of Economics and Finance 63 (2017) 50-65. http:// dx.doi.org/10.1016/j.qref.2016.04.003

Zulkarnain, Arif., Mayes, Anthony., Kornita, Sri Endang., (2015). Pengaruh Capital Inflow Terhadap Pertumbuhan Ekonomi di Indonesia Periode 2001-2012. Jom FEKON Vol. 2. No.2. $\quad$ https://jom.unri.ac.id/index.php/ JOMFEKON/article/view/7896 